\title{
Jean Lorrain, Lettres à Gustave Coquiot
}

\section{Ida Merello}

\section{Q OpenEdition}

\section{Journals}

\section{Edizione digitale}

URL: http://journals.openedition.org/studifrancesi/9011

DOI: 10.4000/studifrancesi.9011

ISSN: 2427-5856

\section{Editore}

Rosenberg \& Sellier

\section{Edizione cartacea}

Data di pubblicazione: 1 octobre 2008

Paginazione: 485

ISSN: 0039-2944

\section{Notizia bibliografica digitale}

Ida Merello, «Jean Lorrain, Lettres à Gustave Coquiot», Studi Francesi [Online], 155 (LII | II) | 2008, online dal 30 novembre 2015, consultato il 12 janvier 2021. URL: http://journals.openedition.org/ studifrancesi/9011; DOI: https://doi.org/10.4000/studifrancesi.9011

Questo documento è stato generato automaticamente il 12 janvier 2021.

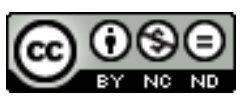

Studi Francesi è distribuita con Licenza Creative Commons Attribuzione - Non commerciale - Non opere derivate 4.0 Internazionale. 


\title{
Jean Lorrain, Lettres à Gustave Coquiot
}

\author{
Ida Merello
}

\section{NOTIZIA}

JEAN LORRAIN, Lettres à Gustave Coquiot, Paris, Champion, 2007, pp. 230.

1 Pregevole edizione della corrispodenza tra Lorrain e lo scrittore e critico d'arte Coquiot, di cui viene presentato anche un breve profilo biografico. L'A. si basa per il suo lavoro su una prima catalogazione di Georges Normandy, che aveva immaginato un'edizione in tre volumi, ma, non soddisfatto del primo volume, aveva lasciato in bozze il secondo e copiato trecento lettere per il terzo. L'A. ha ripreso i testi trascurando le correzioni di Normandy che li rendevano illeggibili, ha corretto la datazione e ha aggiunto altre lettere ritrovate o acquistate all'asta. In appendice, l'A. ha inserito alcuni testi di Coquiot su Lorrain (tra cui una prefazione a l'Histoire des masques), altri di Lorrain su Coquiot e un piccolo dossier di testi diversi su Lorrain, tra cui il racconto del suo arresto a La Spezia, uscito su «Le Petit niçois» del 1904 e il resoconto dei suoi funerali. 